\title{
Nietzsche's Pelagianism: Dionysus versus the Crucified
}

\author{
Bradley Kaye ${ }^{1}$
}

\begin{abstract}
"Perhaps I am even envious of Stendhal? He took away from me the best atheistical joke that precisely I might have made: "God's only excuse is that he does not exist."

(Nietzsche, Ecce Homo, “Why I am so Clever,” \3)

"Theologically speaking - listen closely, for I rarely speak as a theologian - it was God bimself who at the end of his days work lay down as a serpent under the tree of knowledge: thus he recuperated from being God. - He had made everything too beautiful. - The devil is merely the leisure of God on that seventh day." (Ecce Homo, "Beyond Good and Evil," \$2)
\end{abstract}

\section{What is Meant by "Beyond Good and Evil"}

What is meant by 'ethics' in Beyond Good and Evil? Typically, the move beyond good and evil is understood to be a move against 'good' and towards evil. When theorists, such as Bataille and his progeny such as Nick Land's 'virulent nihilism,' take this approach, it misses many crucial points that Nietzsche makes obvious. One such point is that evil relies on good as an objective against which it resists. If ethical systems take away the objective sense of good, then the drive towards evil will no longer exist. A problem with this is that if a person's motivation is solely driven by transgressing good, then that person is acting upon a reactive sense of power, merely reacting to the good. The liberatory possibilities in removing good as the point of resistance means that only the truly strong, the ubermensch will be guaranteed the activation of an active will to power. A deeper revelation is the less comforting realization that 'good' and 'evil' are not inscribed into the universe. When we lose faith in an intrinsically ethical universe, then we traverse beyond the comforts of 'good' and 'evil' and drift into deeper channels of nihilism where the construction of 'good' and 'evil' are brought to our awareness as merely projections of our own sophist consciousness. What are we to make of this line in Beyond Good and Evil: "What? Doesn't this mean, to speak with the vulgar: God is refuted, but the devil is not?" On the contrary! On the contrary, my friends. And, the devil - who forces you to speak with the vulgar?"2 If you turn to his notebooks at the time of writing Beyond Good and Evil, he was clearly grappling with the understanding that if God and the Devil were mutually supported then the great fear is that "the world no longer has meaning," because the death of God

\footnotetext{
${ }^{1}$ Bradley Kaye, Erie Community College, United States. E-mail: kayeb@ecc.edu.

2 BGE \ 37.
} 
popularly understood amounts to a stupid proposition: "God is refuted, but not the devil." 3

\section{What is Pelagianism?}

BGE exposes Nietzsche's critique of "free will", as we know, was not a negation of "will"; but "free"-will. Hence, the connections with Pelagianism that I might try to sketch out in this paper, which will be difficult since truly little of Pelagian's work survives. We know very little about his views, and only through secondary sources and the often-negative opinion of he and his followers. The idea is that Pelagius Hereticus may have offered a view of Jesus that is amenable with Nietzsche's view of the Ubermensch. Jesus, not as a "Son of God"; but as a sort of conveyer of self-mastery through spiritual practices, and that each individual might be able to 'will oneself to salvation as self-mastery, not heaven in the afterlife. When Jesus says in the Gospels:

"In my Father's house are many mansions: if it were not so, I would have told you. I go to prepare a place for you." (Gospel of John, 14:2, King James Version)

An interpretation from a Pelagian might state that the mansions are the temples of the body, and the place in heaven prepared by the Father is the self-mastery of our own individual bodies through the process of self-mastery, not a literal interpretation of salvation as heaven in the afterlife. Pelagianism may have an association with the Pelasgians who were forerunners to the Greeks. Considered unlearned barbarians that the Greeks looked upon as savages. Pelagius Hereticus, referred to as the "British Monk" by Augustine, may have lived from the 4th-5th century A.D. may have family connections back to the Pelasgians. Pelagian may mean "islander" as in "pelagic" and it may mean that he lived on the island that is now Ireland, or it may mean that he was Scottish because little is known about him, and it may also mean that his family spans back to the marginal philosophers of ancient Greek philosophy. Any and all of these interpretations give him a politically marginal status in comparison to the established Greek philosophers upon which the early Patristic theologians relied upon to supplant the authority of the burgeoning Roman Catholic Church. Pelagius has the strange distinction of having his name become the term with which the church used to describe philosophies that are 'heretical.'

The teachings of Pelagius are generally associated with the rejection of original sin and the practice of infant baptism. Although the writings of Pelagius are no longer extant, the eight canons of the Council of Carthage provided corrections to the perceived errors of the early Pelagians. These corrections include:

Death did not come to Adam from a physical necessity, but through sin.

New-born children must be baptized on account of original sin.

Justifying grace not only avails for the forgiveness of past sins, but also gives assistance for the avoidance of future sins.

\footnotetext{
${ }^{3}$ Unpublished Fragments: (Spring 1885 - Spring 1886), August-September 1885, translated with an afterword by Adrian Del Caro. pg. 182., same line is repeated again closer to the publication of BGE in Autumn 1885 - Spring 1886, "God is refuted, but not the devil." pg. 285.
} 
The grace of Christ not only discloses the knowledge of God's commandments, but also imparts strength to will and execute them.

Without God's grace it is not merely more difficult, but absolutely impossible to perform good works.

Not out of humility, but in truth must we confess ourselves to be sinners.

The saints refer the petition of the Lord.

The saints pronounce the same supplication not from mere humility, but from truthfulness. ${ }^{4}$

In 418 A.D. the Council of Carthage decided that the acts described in Genesis constituted an 'original sin' that effects all of humanity and the acts of Adam and Eve put the stain of sin in all human beings. Pelagius correctly asserted that since there was no 'original sin' mentioned in the Genesis story, the acts of Adam and Eve did not universally effect all of humanity, did not win favor in the Roman Catholic Church.

If, as Nietzsche claimed, truth is a kind of error, why did the Church find Pelagius in error when establishing its principles and dogmas as a religious institution. Pelagius argued that human will, with its abilities created by God, was sufficient to ensure human salvation. Pelagius was disturbed by the immorality he encountered in Rome and saw Christians using human frailty as an excuse for their failure to live a good life. He taught that the human will, as created with its abilities by God, was sufficient to live a sinless life, and hence true believers in the teachings of the Gospels may not necessarily need to rely on the baptismal sacraments offered by the church to have salvation bestowed upon them.

In other words, the Catholic Church held no hegemonic position with regards to bestowing God's grace upon believers in Christ. Pelagianism may have taught that anyone who exerted strong will with regards to living a virtuous life could take the teachings in the Gospels, think for themselves, and find their own personal path to salvation, here on earth, through the exertion of personal strength of will. Little is known about why Pelagian thought died out, but clearly, it posed a threat to Church hegemony insofar as the "correct" interpretations of the Bible. Pelagius Hereticus, the founder of Pelagianism, also became the namesake for the worst kind of scriptural error of interpretation - he was the first "heretic," a crime that originated from Pelagianism. If we take Nietzsche seriously when he says, time and time again that "truth is a kind of error," then we know that in the eyes of the Church, Pelagius was in 'error' precisely because he spoke the truth.

He cited Deuteronomy 24:16 as evidence of his thesis that original sin must not be understood as a universal sinfulness that applies to every single human being. The passage reads: "Parents are not to be put to death for their children, nor children put to death for their parents; each will die for their own sin." 5

\footnotetext{
${ }^{4}$ Cited from the "World Heritage Encyclopedia" and all references to Pelagius are henceforth referenced from that source.

${ }^{5}$ What the passage from Deuteronomy addresses is the issue of moral pollution. For those who have read the Platonic dialogue entitled the Euthyphro, it describes an example of how important the idea of moral pollution was to the Greeks.
} 
Clearly indicating that there is no transmission of the sins of Adam and Eve to all human offspring, but their acts only affected them. Besides the politics of his ethnic origins Pelagius' work bears a strange resemblance to some of the vital concepts in Friedrich Nietzsche's philosophy. Beyond the fact that most of the fables in the Bible were poorly appropriated from Hesiod's epic story in Works and Days, there are pastoral myths that were cast aside from mere story telling into religious dogmas.

One can think of the line from Michel Foucault in Nietzsche, Genealogy, History: "Genealogy is gray, meticulous, and patiently documentary. It operates on a field of entangled and confused parchments, on documents that have been scratched over and recopied many times. On this basis, it is obvious that Paul Rée was wrong to follow the English tendency in describing the history of morality in terms of a linear development - in reducing its entire history and genesis to an exclusive concern for utility. He assumed that words kept their meaning, that desires still pointed in a single direction."' The interpretations of the Bible in lieu of this discussion obviously take a genealogical sense of interpretation, rather than a settled business of reified hermeneutics that would indicate one objective interpretation.

Perhaps Pelagius was arguing that the Biblical understanding of sin must not frame its moral categories in terms of social relativism and the transference of pollution from one family member to another, or one community member to another. Each individual must deal with their own decisions as a matter of personal will and the will of each human individual contains the potential to overcome the temptation of sin. Therefore, one cannot apply the sins that occurred in the Garden of Eden to every single human individual as a universal 'fall.'

As Heidegger knew very well the etymology of the word "fall" derives from the Latin "falsum" to falsify, and bringing to fall, to topple. The emergence of the 'correct' interpretation of the Fall story is grounded upon the politicizing of the story by falsifying and toppling alternative readings of this convincing fable. In doing so, the politics of the Roman Catholic Church, basing its metaphysics upon a hierarchical system inherited from Aristotle's "Great Chain of Being" wanted to bring non-believers into the flock by propagating the myth of origin story that claimed every human being was inherently broken and in need of redemption through Christ, whose word was passed on through the fidelity of the Church as an institution, touched by grace due to surviving the sack of Rome in August of 410 A.D. by King Alaric leader of the Visigoths.

A mere eight years later in 418 A.D. the Council of Carthage would decide church doctrine consists of 'original sin' effects everyone. The same year a "foederati" (root word is 'fi-des' or 'fidelity' to a truth) was struck between the Roman Empire and the Visigoths in where they agreed to become mercenaries and fight on behalf of the Roman Empire as willing

A man named Euthyphro bumps into Socrates while they are both walking into the home of the Athenian magistrate who would settle their court cases. Euthyphro discusses his case with Socrates by explaining that he is bringing a case against his father for the death of Euthyphro's slave, and Euthyphro expresses concern about concluding the case because his father is old and could die before the issue of moral pollution caused by the unethical act is cleared up. He explains: "The pollution is the same if you knowingly keep company with such a man and do not cleanse yourself and him by bringing him to justice." (Euthyphro dialogue, line 4c-d).

${ }^{6}$ Michel Foucault. "Nietzsche, Genealogy, History." The Foucault Reader, ed. Paul Rabinow, 1984, pp. 76. 
soldiers $^{7}$ a political move as well, where the Visigoths were forgiven of their sins conveniently by the same Holy Roman Empire that in the same year decided 'original sin' was an actual thing, thereby espousing the belief that in being conquered the church could then 'forgive' the conquering armies of their sins and turn them into 'good soldiers of Christ.'

In 426 A.D. then St. Augustine writes his superior work, less read but far more interesting than the Confessions, his masterwork City of God where his thesis is simple. Even though it takes over a thousand pages of spilled ink he declares that the city of Rome is the shining example of God's grace because the leaders of the church tactfully turned back the tide of violent invasions. The fact that the Church survived several sacks on Rome must have meant that God played a role in those events.

Obviously, historical context plays a role in deciding Church policy, but it was not completely accepted as full Catholic doctrine until the Council of Trent in the 16th century even though it was first forwarded as scripturally informed religious theology as early as the 2 nd century A.D. by Irenaeus, Bishop of Lyon as a rebuttal to the gnostic interpretations of the Bible.

I bring this up not so as to get into the heavy weeds of early catholic patristic theology, a topic that might not be so interesting to readers of Nietzsche (except those of us who are Foucauldians), but because it seems as though Nietzsche's writings tend to have this uncited siding with the losers in these battles. Even the Gnostics with their Gospel of Judas and the appropriation from the Greek understanding of 'gnosis' as mirroring, where the basis of spiritual identity in any metaphysical sense is more or less a mirroring process where the self-projects to the heavens what it is within, and spiritual exercises consist of cleansing the soul/mirror so as to see within/above clearly.

These are most aptly described by Nietzschean disciples like Heidegger who say, man was not created in the image of God, God was created by mankind in our image. It is tragic that it took centuries of dark age mentality before the critique of metaphysics offered by Nietzsche could break through this monolithic edifice of church doctrines (which today, these critiques may seem like ordinary common sense).

Pelagius Hereticus, whose name may have been derivative of the Pelagianist "barbarians," was so controversial that he is considered to be the first heretic, and his name was renowned as the standard by which the church would ostracize heretical beliefs. Augustine of Hippo declared that Pelagianism, with its main tenets being the lack of belief in original sin, amounted to the elevation of the prideful attributes of self-love over and above the requisite humility required for the love of God. If a person is to accept the love of God and the grace of salvation offered by Jesus then that person must humble themselves and place a higher importance upon God.

However, one does not need to have Nietzsche explain that God is not humble; one merely has to read the Bible. Nietzsche's interpretation of the character of God in the Genesis story is that it mirrors the ressentiment of Adam and Eve who in doing what they wanted by eating the fruit of knowledge immediately felt shame. God went too far, created something so beautiful, so perfect, so blissful that it immediately felt shame and then in a

${ }^{7}$ See 2nd Timothy chapter 2 "Good Soldiers of Christ." 
moment of dubiousness created the serpent knowing that Adam and Eve would have to be cast out. It is easy to forget that when writing these fables there was not an established policy as to the correct interpretation of the stories. Original sin did not become the official doctrine of the Roman Catholic Church until the Councils of Trent in the 16th century. Prior to that time the doctrine of original sin was an unsettled debate the "correct" interpretation of the Garden of Eden story had not yet been established.

Therefore, when Nietzsche says, "truth is a kind of error," and he takes a genealogical approach where the truth is, as Foucault states: "gray, meticulous, and patiently documentary. It operates on a field of entangled and confused parchments, on documents that have been scratched over and recopied many times." 8

\section{Phantasmagorial Myths}

Phantasm is one of the vital concepts in the Nietzschean oeuvre. Rather than forwarding theses in the sense of pushing an argument based in propositional logic, a tradition in philosophy that spans at least as far back as the Platonic dialogues, most commonly you see Nietzsche giving off intensities and writing 'experience books." In the writing itself gives off sparks, pulsions, power and provokes an excitability in the reader. Phantasms are subterranean intensities buried deep in the subconscious that are undetectable to the surface levels of the conscious rational mind.

A phantasmagorical myth is shot through with illusions, misleading appearances, a deceptive shape or shadow perhaps produced by a magical lantern. ${ }^{10}$ Nietzsche's "madman" brings the light when there is already light, hence, he arrives at the wrong time, when the enlightenment of Christian faith has spread to the point where its enlightenment has become the apogee of all civilized life. No one yearns to hear the truth which has come too late, the Death of God arrived thousands of years after the rise of the Christian conceptual personage. Nietzsche's lantern-bearing "madman" also bears a striking resemblance with the Hermit figure in the Tarot Deck, whose light looks downward from the heights of a precipice, and whose light is cast during the light hours of daytime, the Hermit is always a figure of alterity who casts a gaze from outside the norms of society from a position of solitude - such as Nietzsche's Zarathustra who came out from the Cave after years of solitude to spread the word of the Death of God, a message whose time had not yet arrived.

When the young Nietzsche writes, "concepts are metaphors that do not correspond to reality," and "truths are illusions about which one has forgotten that this is what they are;

\footnotetext{
${ }^{8}$ Michel Foucault. "Nietzsche, Genealogy, History." The Foucault Reader.

${ }^{9}$ A phrase used by Foucault to describe his own work and most certainly an homage to Nietzsche.

${ }^{10}$ It is no small detail that the alleged 'madman' who bears the news that God is Dead comes bearing a lantern in hand at the break of dawn. Why he would need such a lantern at the break of day is of no small consequence, he is both bearer of light, bringer of a new dawn, and provoking a new set of phantasmagorical myths to emerge as the end of the 'Greatest Stress' passage in the Joyful Science implies. It should also be noted that the aphorism of the 'Greatest Stress' is told in the third person. The story is told second-hand and the 'madman' does not apply this monikker to himself. As is now common science with the Dunning-Kruger Effect, no one is aware of their own lack of mental ability, and we are all ready to criticize others, either to overestimate or underestimate the abilities of the others in accordance with our own levels of cognition. So, the labelling of the 'madman' as mad clearly has to be done from the perspective of someone who holds the opinion "God is Dead" to be a flawed opinion, and yet the irony is that in calling the 'madman' as such, the narrator shows an inability to form meta-cognition on the level of self-criticism of theological first principles.
} 
metaphors which are worn out and without sensuous power..." and that "One might invent such a fable," only to later fall into the habit of true belief because we forget what the intellect is: "the intellect, as a means for the preservation of the individual, unfolds its chief powers in simulation; for this is the means by which the weaker, less robust individuals preserve themselves..."

The people who wrote the Bible knew that they were writing a fable. Being remote from those people now, whose lives have been lost to time, and who have created a mythical set of super-human characters that seem larger than life, we have forgotten that they knew it was a fictional story, not to be taken literally. The fact that the news of God's death has come too early, even though a century has passed since Nietzsche wrote these startling words, perhaps he was right to say that even a century later the world is still not ready to hear these words and therefore must comfort ourselves with "festivals of atonement" and the invention of "sacred games,"11 to secure the abyss of freedom as this discovery that God is Dead leaves a boundless "open sea"12 before us.

For example, the Adam and Eve story was a fable subject to interpretation like any other work of narrative storytelling sprung from human imagination, it was not a pragmatic toolmaking, problem solving equation that was used to explain beyond a reasonable doubt the origin of the human species and the origin of the cosmos. It would be absurd to genuinely believe that those who wrote the book of Genesis thought they were reporting as if from a journalistic fact-gathering perspective, it is absurd because there cannot be any first-hand accounts of the creation myth, unless you interviewed Adam and Even directly, however, the story begins prior to their existence. Which poses a serious credibility problem to the truth of the story, only if you take the story to be factual, it is crucial to remember that it is an illusion, a narrative, a fable like any other fable and was written under those pretexts. To be technical, it was spoken and passed down through oral tradition prior to being incarcerated by the written text.

What is crucial in Nietzsche's correct interpretation of this story is that it is a phantasmagorical myth. Phantasmagoria was a form of horror theatre that projected frightening images such as skeletons, demons, and ghosts onto walls, smoke, or semitransparent screens, having a fantastic or deceptive appearance, as something in a dream or created by the imagination. having the appearance of an optical illusion, especially one produced by a magic lantern. Notice that when Nietzsche's 'madman' declares the death of God he does so while carrying a lantern. The insinuation is clear. God is meant to be a horrifying image, but nothing more than a shadow cast upon the wall of a cave.

"The unfree will is mythology; in real life it is only a matter of strong and weak wills." (Beyond Good and Evil, \$21) Where might we place Nietzsche on the issue of free will and determinism, or free will and destiny? The question has been framed wrong. It is not "free or unfree will" as much as the question should be "strong and weak will." While passages such as the aforementioned lines from Ecce Homo and Beyond Good and Evil draw a crystal clear vision of Nietzsche's atheist pelagianism, one has to remember the irony, absurdism, and the truth and lying in an extra-moral sense that Nietzsche recurrently evokes. Lines like: "These outcasts of society, these long-pursued, wickedly persecuted ones - also the

${ }^{11} \mathrm{GS} \$ 125$.

${ }^{12} \mathrm{GS} \$ 343$. 
compulsory recluses, the Spinozas or Giordano Brunos - always become in the end, even under the most spiritual masquerade, and perhaps without being themselves aware of it, sophisticated vengeance-seekers and poison brewers...not to speak of the stupidity of moral indignation, which is the unfailing sign in a philosopher that his philosophical sense of humor has left him." (BGE, \$25) and remember, even Plato kept "under the pillow of his deathbed" a "volume of Aristophanes." (BGE, \$28), but also being careful to note that "it was reported of the young Plato that he never laughed excessively."13

What is the connection between Pelagius and Nietzsche? I think it boils down to the subtlety in the passage from BGE \#21 - "the unfree will is a mythology, there are only strong and weak wills" - and I will try to make this clearer, because I think this is the central point at which Pelagianism and Nietzschean "will to power" converge. If there is a way to understand Jesus as a figure of spiritual self-mastery, rather than as "Son of God," then there is a link between the early intentions behind the writing of the Gospels and the later view of the Catholic Church centuries later, when the Catholic Church post-haste aposteriori concluded that the texts of the Bible were indicating a general, universal application of something called "original sin," then, if we look at the fact that this interpretation did not originate until several centuries later, then there can be no dispute that the biblical text itself was not written under the divinely inspired word of God, indicating some sort of infallible view cast from above through the pen strokes of those who wrote the original text. It is, as Foucault's interpretation of Nietzsche's genealogy bears worth repeating, not a linear progression, but "operates on a field of entangled and confused parchments."14

None of Pelagius Hereticus' writings survive. All that we know about his writing is from the Council at Carthage where the Catholic Church "corrected" what his followers believed to make it in accordance with what the Church wanted people to believe was the correct interpretation of the book of Genesis (and henceforth probably destroyed most of his philosophy so as not to infect the people with his 'heretical views' - Pelagius Hereticus was the namesake for the term 'heretic' and I do see many references to heretics in Nietzsche).

Nowhere in those corrections of Pelagianism is there any mention of "Free will"; but rather there is mention of correcting the pelagian belief that human will does not need to rely on God's grace to find salvation. Rather than God's grace choosing you for salvation, the Pelagians it seems may have forwarded a belief that Jesus was a sort of spiritual guide and each individual has it in their power to exert a "strong will" to practice the teachings of Jesus and improve themselves (i.e. Jesus is a kind of ubermensch sent by God and we all have the power to improve ourselves to become ubermensches - rather than, ressentiment filled servants. Free and unfree will works well as a narrative that the Church can use to place "responsibility" on individuals and wash its hands, and the hands of powerful leaders who rely on Church rhetoric to create subjects, rather than producing Christianity as a philosophy of "strong and weak willed" believers who view Christ's teachings as a guide for social evolution of the individual in real life, here and now. In fact, the early Christians were more likely to interpret Christ's teachings as if they were spiritual exercises. The

\footnotetext{
${ }^{13}$ Friedrich Nietzsche. Introduction to the Study of the Platonic Dialogues.

${ }^{14}$ Foucault. Nietzsche, Genealogy, History. 
"desert fathers" as the early Christian Monks were called, tended to see the Jesus who spent 40 days and 40 nights in the desert, not as metaphors, but as literal testaments to the need to be "strong willed" and literally push yourself to extreme moral asceticism to actually enhance the physical body and push it to new levels of moral and spiritual temperance. $^{15}$

Hence, Nietzsche's view that human will is the power that creates values (and subsequent transvaluations) is something that ${ }^{*}$ might* bring Nietzsche and Pelagius into alignment, because perhaps by seeing Pelagius as the "losing side" of the debate on original sin we have to remember that the hegemonic interpretation of the Biblical texts as produced by the Roman Catholic Church were not always established doctrine as such. There were debates that lasted centuries some of whom, like Pelagius, had perfectly reasonable interpretations that simply lost their persuasiveness because they did not serve the function of enhancing the institutional power of the Roman Catholic Church as a social institution.

Plato in a way ruins the interpretive openness of philosophical inquiry because the love of wisdom means that "he had to live in a way to become ever more appropriate for his ideal, there had to be a correspondence of identical mimesis between the subject and the object. Which creates this terrible momentum behind a tendency towards a very restrictive understanding of realism as the good end of philosophical inquiry. To find the thing and its qualities, the quid and the quale is to discover what it actually is in its identity, its truth has to do with how the idea of the thing in the mind faithfully represent the thing-in-itself with clarity.

However, if we take Nietzsche's anecdote at face value then the authenticity required by Plato is an ironic authenticity, the forms are a humorous irony that humans strive towards within this life, without any hope of obtaining the perfection of form because perfection is only accessible in the mind of the gods through 'anamnesis' (memory work and recollecting the knowledge implanted by the Gods, but only accessible in subterranean regions of the mind, not in our conscious mind). One might take Nietzsche's point "truth is an illusion we have forgotten as such" to mean that the Church, in going with St. Augustine and taking the Platonic theory of forms as seriously informing the proper reading of Biblical texts, as forgetting the ironic playfulness and humor with which Plato created the conceptual personae of Socrates.

It is important that, rather than avoiding all political theological conversations, one rather keep an open-theological approach that is peppered with a strong sense of humor, focused on the absurdity of existence qua existence, rather than vengefulness, jealousy, and the mocking derision of ressentiment. In the lines where Nietzsche casts himself in a way he rarely does, as a 'theologian' you see his analysis of God as drawing back, recoiling, and experiencing ressentiment when God created the serpent on the seventh day.

It was a result of God making existence too beautiful and therefore, 'Crucifying' himself, even the anti-Pelagian version of God was too scared to fully embrace the Dionysiac spirit as "the religious affirmation of life, life whole and not denied in part; (typical that the

\footnotetext{
15 The Desert Fathers: Sayings of the Early Christian Monks, Penguin Classic Edition, published 2003 is a wonderful collection of these early spiritual exercises.
} 
sexual act arouses profundity, mystery, reverence.)" (Will to Power, $\$ 1052)^{16}$ rather than as a master morality of the Dionysiac joyous affirmations of the pleasures in life, the Christian God 'crucifies' all that brings joy, and shepherds its followers into being despisers of the body, yet Nietzsche is espousing a heretical set of views, meant to satirize and emphasize his thesis that "truth is a kind of error," and "will to power is pathos." One may produce (poiesis) new interpretations, not necessarily just to be flippant for its own sake, but to stretch the limits of ortho-doxical (right and wrong in the ordinary commonsense way it is understood), to stretch truth into an extra-moral sense.

\section{Dionysus versus the Crucified}

In the section of Ecce Homo that Nietzsche entitled "Why I am a Destiny" he writes a puzzling penultimate final line in the essay, a sparse line that may summarize the entire corpus of Nietzsche's perspectives on 'open theology' - "Have I been understood? Dionysus versus the Crucified." In being a theology that produces 'despisers of the body,' and forces the trajectory of our being into becoming otherworldly, the phrase "menschliches, allzumenschliches," most scholars brush by the brilliant subtlety of the Human, All Too Human as if Nietzsche were implying a repetition of the Christian essentialist attitude towards human suffering and frailty, missing the obvious point. The Human, singularizing itself from the herd of the All, Too (many) Humans.

The Ubermensch, the human that is above and beyond, seeing from atop a mountain, from a higher perspective, attaining its most perfect form, must distance itself from the mediocrity of the shepherding of Christianity and its fatalistic anti-Pelagianism.

Pelagianism is the understanding that the word, "original sin," never occurs in the book of Genesis. It would be an exegesis to ascribe the stain of original sin to all of humankind it is a human bias inserted into the text to ascribe a sentiment, such as original sin to the text when that interpretation is not transparent. Curiously, Heidegger notes ${ }^{17}$ that the words 'falsum,' and 'fall' have to do with error and bringing to fall, or the loss of power, and are etymologically in a genealogical lineage with the Greek words for 'making topple,' and 'misleading,' with the connotation being an unsturdy base and ungrounding of support for the truth. Hence, there is a thematic aspect to Nietzsche's work that some have read as anti-foundationalist. ${ }^{18}$

\footnotetext{
16 Obviously, there was a recoiling effect with some theologians now rendering the serpent in Genesis 3:1 as 'naked' with the fig leaf being a necessary 'concealment' of the 'animal vigor' associated with the joy of creation and aesthetic pleasure, an anti-metaphysical urge to unity and enjoyment. Nietzsche's Pelagianism as the 'Anti-Christ' is not some satanic propaganda, but a recognition that the arrival of the serpent as the evil-phallic signifier is the moment of God's castration. Rather than 'sin' entering into the world the Garden of Eden myth is the moment when 'shame' enters the world. A completely different connotation with 'original sin' carrying an essentialist permanence to it, a transcendent a-priori when it is a slave morality that has infected all aspects of human moral conscience. This cautious God has infected the Logos, the ressentiment of a reflecting God who retracted the gift of connubial bliss in the prelapsarian utopia of Eden.

${ }^{17}$ Martin Heidegger. Parmenides, translated by André Schuwer and Richard Rojcewicz, Indiana UP, 1998, pg. 39-49. Heidegger argues that this theme of falsum, falsifying, making fall, bringing to topple, has an epistemological legacy inextricably linked with occidental power.

${ }^{18}$ Cornel West. "Nietzsche's Prefiguration of Postmodern American Philosophy." boundary 2, Volume 9 \$3, "Why Nietzsche Now?" 1981. One of the most comprehensive journal article length works of scholarship on the influence of Nietzsche upon twentieth century American Philosophy. Professor West has provided a very careful, detailed, an immensely useful resource for Nietzsche scholars looking to trace the lines of his thought into postmodern philosophy.
} 
While the Will to Power $\$ 1052$ does offer a summation of this conflict within the self and within Christian society, there are other summations throughout Nietzsche's work including in Ecce Homo where he succinctly says:

"I was the first to see the real opposition: the degenerating instinct that turns against life with subterranean vengefulness (Christianity, the philosophy of Schopenhauer, in a certain sense the philosophy of Plato, and all of idealism as typical forms) versus a formula for the highest affirmation, born of fullness, of overfullness, a Yes-saying without reservation, even to suffering, even to guilt, even to everything that is questionable and strange in existence." (EH, "The Birth of Tragedy" \$2)

Perhaps Nietzsche's views on Christianity, as he said he did not merely criticize Christianity by coming as the Anti-Christ (i.e. the transvaluation of Christian values), but as the philosopher who provided the unconcealment of what Christianity actually was and is, in rebuking the myth of original sin, he draws out the most violent and repressive aspects of ressentiment, the suffering for suffering sake, the mindset of a true believer who thoroughly throws his life away believing that no amount of suffering is ever enough to become equal to the passion of Christ, the Crucified. As if to say in purely Manichean rhetoric that if there is an original sin, there must be a telos of salvation.

Any suffering, as a nihilist would claim, is suffering that can never resort to an actual sacred canopy for protection. Total and absolute skepticism towards any religious ethos of taking on the burden, lightening the cross, carrying another's cross. The guidance one seeks from a metaphysical entity such as God is a figment of the imagination. Salvation is hoped for and never actually existing phenomenon. For the nihilist the same holds true for the telos of suffering, or the redemption one might hope will one day reveal the true meaning in the suffering that is omnipresent in existence. If the belief is that there is original sin because God makes no mistakes, then all humankind is stained by the Fall. According to this interpretation, we are all sinners, unworthy of receiving the gift of salvation until the Messiah arrived, and until we choose to accept Christ as the savior. The spirit of God will then awaken the Spirit of Christ in us and with practice the true believers will find salvation, through ongoing committed worship of God as manifest in the body of Christ and a lifelong practice of reading, praying, and focusing on the teaching of Jesus one can awaken a better life in themselves.

The belief in Grace, is the belief that then the redemption from original sin can only happen through God's will, not the will of man. God will shine grace on those who are worthy, and no act of the will to power can save a person, unless that will is the will of God and formed within the logos, ethos, and pathos ${ }^{19}$ of spiritual exercises outlined within a scriptural context. There are no references to the word "Pelagianism" in any of Nietzsche's works. If it was a theological perspective he felt aligned with, it was something he kept concealed, and one would have to ask why, but more likely he was unfamiliar with

${ }^{19}$ I specifically chose to use the philosophical terms: Logos, Pathos, Ethos to indicate the Greek origin of the terms that Christians would commonly use - "Mind, Body, and Spirit," Logos as the thought process proper to God, Pathos as the sanctity of the body and the preservation of a sacred sense towards the body in its appetitive attitudes, and Ethos as the spirit of the laws, the spirit of what is believed. These premises that form the backbone of Christian commitment go back to an appropriation from the Platonic conception of the Tripartite Soul - Reasoned, Appetitive, and Spirited sides to the self as outlined in the Republic, line 435-end of Book IV. 
Pelagius, or had not read it very closely, but for large stretches in his life Nietzsche was not reading anything. ${ }^{20}$ This was clearly a way for Nietzsche to cleanse his mind of the need to echo what someone else wrote and to dig into himself to find out his own inner voice, and if anything, when he read, it was to find the tempo of the words. To read was to read with a 'third ear'21 to read so as to inwardly listen to the tempo of the words and to hear the beauty in it, not in the sense of a proportional equilibrium where beautiful poems have a perfect rhyming scheme, but a somewhat off-putting syncopation to the flow that catches the attention of the listener.

Pelagius $^{22}$ rejected the Biblical concept of grace, which is the belief that only God can accrue salvation upon humanity and that no human perfection is possible while living on earth. His opponents included St. Augustine whose interpretation of the Garden of Eden story as indication of original sin was favored by the Roman Catholic Church and eventually won out as the correct interpretation of the Adam and Eve story. Pelagius taught moral perfection (to put it in Nietzsche's verbiage, he may have called this a moral Ubermensch) was attainable in this life without the assistance of divine grace through human will. Although Nietzsche is not a believer in total and absolute free will, there are gaps here and there where you can start to see Nietzsche truly believing in "amor fati" (love of fate). To realize that you are strapped to your body is to love the fate of the corporeal form that your will has taken:

"Let me tarry over the psychology of the good human being. To estimate what a type of man is worth, one must calculate the price paid for his preservation - one must know the conditions of his existence. The condition of the existence of the good is the lie: put differently, not wanting to see at any price how reality is constituted fundamentally - namely, not in such a way as to elicit benevolent instincts at all times, and even less in such a way as to tolerate at all times the interference of those who are myopically good-natured. To consider distress of all kinds as an objection, as something that must be abolished, is the niaiserie par excellence and, on a large scale, a veritable disaster in its consequences, a nemesis of stupidity..." (Ecce Homo, Why I am a Destiny, \$4)

Augustine, in forwarding his thesis on original sin and the necessity of grace differentiated his position from Pelagius by saying that perfection was impossible without grace because we are born sinners with a sinful heart and will. The Pelagians charged Augustine with departing from the accepted teaching (e.g.: John 8:11) of the Apostles and the Bible because in saying, "Jesus said, neither do I condemn thee, go thy way and sin no more." Clearly, Jesus was saying that he had the power to grant salvation from sin, which is the

\footnotetext{
20 As he says in Ecce Homo: "My eyes alone put an end to any bookworm behavior, in plain language: philology: I was redeemed from the 'book', I did not read anything else for years - the greatest blessing I ever conferred on myself! - That lowermost self, buried and silenced by constantly having to listen to other selves (- and that would certainly mean reading!), slowly woke up, shyly and full of doubts, - but it finally started talking again." (Ecce Homo, "Human, All Too Human" \$4)

${ }^{21}$ Beyond Good and Evil. \$246.

22 Pelagius Hereticus as the name indicates was widely considered one of the "Great Heretics" for not accepting the notion of grace as the path to salvation from the burden of original sin. Hence, Nietzsche's line repeated throughout most of his books "truth is a kind of error," clearly indicates that in his philosophy, truth carries with it the risk of transgression, and the will to truth "does involve risk, and perhaps there is none that is greater." (BGE, $₫ 1$ ) It is easier to recoil into a necessary illusion than to boldly say "God is dead" and take that thesis all the way to its end, which in some cases carries a risk that it may get you killed, as with the heretics and the "disciples of a martyr suffer more than the martyr." (HatH, \$582)
} 
famous scene where the teachers of the law and the Pharisees bring Jesus a woman who has committed adultery and say that the law claims they must now stone her. Jesus says, "Let he who is without sin cast the first stone," and then says that he does not condemn her, go and sin no more.

The Pelagian argument taught that the flesh was in itself sinful, the woman had committed a sin of the flesh by committing adultery, and yet, with Jesus asking the crowd if any among them were without sin the response indicates that among the people in the crowd there were no exceptions to the rule of sin, an Augustinian interpretation might say that this is proof of original sin. All the people in the crowd had some form of sin weighing on their conscience and therefore, no one was pure enough to stone the adulterous woman. The argument from the Pelagians hinges on how the figure of Jesus factors into the story. Was Jesus the embodiment of God, or did Jesus actually come in the flesh, which would imply the understanding that Jesus would at the very least be subject to the temptations of the sins of the flesh. Therefore, if Jesus was the flesh and blood embodiment of God the Father sent to earth, then anyone who is born of flesh and blood can exert "strong will" and overcome sin without being touched by the "Grace of God" as the Augustinians believed. The Pelagians were clearly a dangerous threat to the growing hegemony of the Catholic Church because what they were saying is that anyone who took the teachings of Jesus as spiritual exercises that anyone could do on their own, would no longer need the baptismal rights of the Church to bestow "grace" and salvation from God. Essentially, the institution of the Church itself would be threatened because individuals could use the gospel teachings of Christ to learn their own strength of will, rather than ressentiment and docility, with the power of saving grace in the hands of the Church.

To drive this point even further, there were apocryphal gospels that were in common use in the Vulgate ${ }^{23}$ version of the Bible that were then left out during the King James standardization process.

There are suppressed books of the Bible, the Aporrypha ${ }^{24}$, and books composed by the Gnostics such as the Gospel of Judas, ${ }^{25}$ all of which may have factored into these discussions with the point of my work being that to look at those debates historically one realizes that this is precisely Nietzsche's project in historicizing the Genealogy of Morality, one reveals that the "genealogy is gray, meticulous, and patiently documentary. It operates on a field of entangled and confused parchments, on documents that have been scratched over and recopied many times." 26

\footnotetext{
${ }^{23}$ The Vulgate is the translation of the Bible directly from Hebrew to Latin. It was finished by Jerome in 405 A.D. and St. Augustine offers words of praise towards Jerome when he says Book XVII ch. 43 of his City of God that: "in our own day the priest Jerome, a great scholar and master of all three tongues, has made a translation into Latin, not from Greek but directly from the original Hebrew." In City of God all of the cited sources that Augustine uses to back up his arguments with a scriptural basis are cited from the Vulgate.

${ }^{24}$ Gospel of Mary where Jesus is shown kissing her.

${ }^{25}$ A work of fiction perhaps written by the Gnostics in the 2nd century A.D. imagining conversations between Jesus and Judas.

${ }^{26}$ Michel Foucault. "Nietzsche, Genealogy, History.” Foucault Reader, pg. 76.
} 


\section{Ubermensch as Oneness (the quilting-point)}

"I am the root and the descendent of David, the bright morningstar." (Revelations 22:16)

"There is no male nor female, no Jew nor gentile, no slave nor freeman in Christ."

(Galatians 3:28)

The end of Revelations gives us the very last thing that Jesus says in the entire Bible. It is a strange prelude upon which the Bible ends. The very last phrase is Jesus telling us that he is returning (will there be an eternal return)? Once time stops it starts up again and the cycle happens over and over again and again? Perhaps, we do not know for sure, as with anything the story is a useful narrative not to be taken literally, but the indication that Jesus is 'alpha and omega' the beginning and end could indicate a repetitive loop to eschatological time. The time of the end times is a continuous end in that the future is uncertain and the end always seems near. Lucifer means 'light-bearer' in ancient mythology and often is translated interchangeably with 'morningstar' as in Isaiah 14:12 where the passage reads: "How art thou fallen from heaven, O Lucifer, son of the morning! How art thou cut down to the ground, which didst weaken the nations!" Jesus is the morning star, Lucifer is son of the morning, in that Jesus ultimately holds a superior position; however, the dichotomy runs throughout the Bible. As Judas' fate is sealed with a kiss "phileo" as emotional love rather than "agape" or rational love. Indicating that Jesus cared about Judas' damnation.

It is clear that the figure of Jesus is linked to Lucifer, perhaps they are beyond good and evil as two sides of the same coin. 